\title{
Perbandingan Persentase Lemak Tubuh Sebelum dan Setelah Melakukan Senam Zumba pada Wanita Dewasa
}

\author{
${ }^{1}$ Brigitta A. Tendean \\ ${ }^{2}$ Damajanty H. C. Pangemanan \\ ${ }^{2}$ Ivonny M. Sapulete
}
${ }^{1}$ Program Studi Pendidikan Dokter Fakultas Kedokteran Universitas Sam Ratulangi Manado
${ }^{2}$ Bagian Fisiologi Fakultas Kedokteran Universitas Sam Ratulangi Email: gittatendean@gmail.com

\begin{abstract}
Physical activity is a body movement produced by skeletal muscles which requires energy. Lack of physical activity has a negative impact, one of which is an increase in body fat percentage above the normal threshold or often associated with obesity. Zumba is one of the popular aerobic exercises in the form of dancing. This study was aimed to compare the percentage of body fat before and after undertaking Zumba exercise in adult woman. This was an experimental field study with the one group pretest-posttest design. Samples were obtained by using total sampling technique. Zumba exercise was undertaken for 4 weeks, 3 times a week for 60 minutes. The percentage of body fat was measured by using an instrument based on Bioelectrical Impedance Analysis. Data were analyzed with the Wilcoxon Signed Rank test. The results showed that 16 subjects were involved in this study. The mean percentage of body fat percentage before Zumba exercise was $39.300 \%$ (SD \pm 8.1041 ) meanwhile the mean percentage of body fat percentage after Zumba exercise was $39.031 \%$ (SD \pm 7.9232$)$. The statistical analysis to compare the body fat percentage before and after doing Zumba exercise obtained a $P$ value of 0.065 . Conclusion: There was no significant difference in body fat percentage before and after undertaking 4-week Zumba exercise among adult females.
\end{abstract}

Keywords: body fat percentage, Zumba exercise

\begin{abstract}
Abstrak: Aktivitas fisik merupakan gerakan tubuh yang dihasilkan otot rangka yang memerlukan energi. Kurangnya aktivitas fisik seperti olahraga memiliki dampak negatif, salah satunya peningkatan persentase lemak tubuh di atas ambang normal atau obesitas. Olahraga yang sedang popular belakangan ini ialah senam Zumba, yaitu latihan aerobik dalam bentuk tarian. Penelitian ini bertujuan untuk mengetahui perbandingan persentase lemak tubuh sebelum dan setelah melakukan senam zumba pada wanita dewasa. Jenis penelitian ialah eksperimental lapangan dengan desain one group pretest-posttest. Teknik sampling yang digunakan ialah total sampling. Senam Zumba dilakukan selama 4 minggu dengan frekuensi 3 kali seminggu yang berdurasi 60 menit. Persentase lemak tubuh diukur menggunakan alat berbasis bioelectrical impedance analysis. Data penelitian dianalisis dengan uji Wilcoxon Signed Rank Test. Hasil penelitian mendapatkan 16 subjek. Rerata persentase lemak tubuh sebelum senam Zumba yaitu 39,300\% ( $\mathrm{SD} \pm 8,1041$ ). Rerata persentase lemak tubuh setelah senam Zumba yaitu 39,031\% (SD $\pm 7,9232$ ). Hasil uji perbandingan persentase lemak tubuh sebelum dan setelah melakukan senam zumba menunjukkan nilai $P=0,065$. Simpulan: Tidak terdapat perbedaan bermakna dari persentase lemak tubuh sebelum dan setelah melakukan senam zumba selama 4 minggu pada wanita dewasa.
\end{abstract}

Kata kunci: persentase lemak tubuh, senam Zumba 
Lemak tubuh merupakan salah satu bentuk sumber energi. Lemak menghasilkan $9 \mathrm{kkal}$ energi per gram lemak yang dikonsumsi. Lemak tubuh juga berfungsi sebagai bagian dari membran sel, mediator aktivitas biologik antar sel, isolator dalam menjaga keseimbangan suhu tubuh, pelindung organ-organ tubuh, serta pelarut vitamin A, D, E, dan K. ${ }^{1}$ Kadar lemak tubuh dinyatakan dalam bentuk persentase sebagai perbandingan dengan keseluruhan komposisi tubuh dengan nilai normal berkisar antara $20-25 \%{ }^{2}$

Persentase lemak tubuh dipengaruhi dua faktor utama yakni konsumsi kalori dan energi ekspenditur. Konsumsi kalori berlebih yang tidak diimbangi dengan energi ekspenditur yang tinggi akan menyebabkan peningkatan persentase lemak tubuh. Energi ekspenditur adalah energi yang dimanfaatkan tubuh untuk menjalankan beberapa fungsinya. Salah satu kompo-nen energi ekspenditur ialah aktivitas fisik. ${ }^{3}$ Peningkatan aktivitas fisik seperti olahraga yang rutin meningkatkan energi ekspenditur dan berpontensi menurunkan persentase lemak tubuh. Penelitian sebelumnya yang dilakukan oleh Permana di Semarang menunjukkan bahwa terdapat pengaruh olahraga aerobik senam body language terhadap persentase lemak tubuh. Penelitian tersebut memperlihatkan rerata penurunan persentase lemak sebesar 2,6\% setelah mengikuti senam body language tiga kali seminggu dalam jangka waktu satu bulan. ${ }^{4}$

Salah satu olahraga yang sedang popular saat ini yaitu senam Zumba. Senam Zumba menerapkan metode High Intensity Interval Training (HIIT), yakni olahraga yang fokus utamanya penggunaan energi dari cadangan lemak. Senam ini menduduki peringkat kesembilan latihan kebugaran yang terpopuler sepanjang tahun 2012 dan saat ini digunakan oleh empat belas juta orang di 185 negara di seluruh dunia., Penelitian ini bertujuan untuk mengetahui apakah terdapat perbedaan persentase lemak tubuh sebelum dan setelah melakukan senam Zumba.

\section{METODE PENELITIAN}

Jenis penelitian ialah eksperimental lapangan dengan desain penelitian one group pretest-posttest. Penelitian dilaksanakan di salah satu pusat kebugaran Manado, Sulawesi Utara pada bulan Oktober-November 2018. Sampel penelitian merupakan wanita dewasa yang rutin mengikuti senam Zumba di salah satu pusat kebugaran di Manado, Sulawesi Utara yang memenuhi kriteria inklusi dan eksklusi dan didapatkan subyek penelitian ini berjumlah 16 orang.

Subyek penelitian melakukan senam Zumba selama 4 minggu dengan frekuensi 3 kali per minggu dan durasi 60 menit. Senam Zumba dilakukan bertahap mulai dari pemanasan selama 10 menit, bagian inti selama 45 menit, hingga pendinginan selama 5 menit.

Variabel bebas pada penelitian ini ialah senam Zumba dan variabel terikat ialah persentase lemak tubuh. Persentase lemak tubuh diukur dengan alat berbasis Bioelectrical Impedance Analysis (BIA) jenis Family Dr Body Fat Monitor FEP103. Analisis data menggunakan Wilcoxon Signed Rank Test.

\section{HASIL PENELITIAN}

Subjek penelitian diwawancarai dan diminta mengisi kuesioner kesiapan aktivitas fisik (PAR-Q) untuk pnyaringan. Setelah itu, subjek yang sudah disaring dan memenuhi kriteria inklusi dan eksklsusi mengisi informed consent.

Karakteristik subjek penelitian berdasarkan usia terbanyak terdapat pada kategori usia 26-35 tahun dan 36-45 tahun masing-masing sebanyak 6 orang $(37,5 \%)$, dan yang paling sedikit terdapat pada kategori usia 16-25 tahun sebanyak 4 orang (25\%) (Tabel 1).

Tabel 1. Karakteristik subjek berdasarkan usia

\begin{tabular}{ccc}
\hline Usia (tahun) & n & $\begin{array}{c}\text { Persentase } \\
(\%)\end{array}$ \\
\hline $16-25$ & 4 & 25 \\
$26-35$ & 6 & 37,5 \\
$36-45$ & 6 & 37,5 \\
Total & 16 & 100 \\
\hline
\end{tabular}


Berdasarkan berat badan, subjek penelitian terbanyak terdapat pada kategori berat badan 51-60 kg sebanyak 9 orang $(56,3 \%)$, dan yang paling sedikit terdapat pada kategori $\leq 50 \mathrm{~kg}$ dan $61-70 \mathrm{~kg}$ masingmasing sebanyak 2 orang $(12,5 \%)$ (Tabel 2).

Tabel 2. Karakteristik subjek berdasarkan berat badan

\begin{tabular}{ccc}
\hline $\begin{array}{c}\text { Berat badan } \\
(\mathbf{k g})\end{array}$ & $\mathbf{n}$ & $\begin{array}{c}\text { Persentase } \\
(\boldsymbol{\%})\end{array}$ \\
\hline$\leq 50$ & 2 & 12,5 \\
$51-60$ & 9 & 56,3 \\
$61-70$ & 2 & 12,5 \\
$71-80$ & 3 & 18,8 \\
\hline
\end{tabular}

Berdasarkan tinggi badan, subjek penelitian terbanyak terdapat pada kategori tinggi badan 147-157 cm sebanyak 11 orang $(68,8 \%)$ (Tabel 3). Berdasarkan indeks masa tubuh (IMT), subjek penelitian terbanyak terdapat pada kategori IMT $\geq 25$ sebanyak 7 orang $(43,75 \%)$ (Tabel 4$)$.

Tabel 3. Karakteristik subjek berdasarkan tinggi badan

\begin{tabular}{ccc}
\hline $\begin{array}{c}\text { Tinggi badan } \\
(\mathbf{c m})\end{array}$ & $\mathbf{n}$ & $\begin{array}{c}\text { Persentase } \\
(\mathbf{\%})\end{array}$ \\
\hline $147-157$ & 11 & 68,8 \\
$>157$ & 5 & 31,3 \\
Total & 16 & 100 \\
\hline
\end{tabular}

Tabel 4. Karakteristik subjek berdasarkan indeks massa tubuh (IMT)

\begin{tabular}{ccc}
\hline IMT & n & $\begin{array}{c}\text { Persentase } \\
(\boldsymbol{\%})\end{array}$ \\
\hline $18,5-22,9$ & 5 & 31,25 \\
$23-24,9$ & 4 & 25 \\
$\geq 25$ & 7 & 43,75 \\
Total & 16 & 100 \\
\hline
\end{tabular}

Rerata persentase lemak tubuh sebelum senam Zumba yaitu 39,300\% dengan nilai nilai minimum $28 \%$, nilai maksimum $63,3 \%$, dan standar deviasi 8,1041. Rerata persentase lemak tubuh setelah senam Zumba yaitu $39,031 \%$ dengan nilai minimum $27,9 \%$, nilai maksimum $62,0 \%$, dan standar deviasi 7,9232 (Tabel 5).
Tabel 5. Persentase lemak tubuh subjek sebelum dan sesudah senam Zumba

\begin{tabular}{ccc}
\hline Klasifikasi & \multicolumn{2}{c}{$\begin{array}{c}\text { Persentase lemak tubuh } \\
(\%)\end{array}$} \\
& Sebelum & Setelah \\
\hline Rata-rata & 39,300 & 39,031 \\
$\begin{array}{c}\text { Std. Deviasi } \\
\text { Nilai }\end{array}$ & 8,1041 & 7,9232 \\
$\begin{array}{c}\text { minimum } \\
\text { Nilai }\end{array}$ & 28 & 27,9 \\
maksimum & 63,3 & 62,0 \\
\hline
\end{tabular}

Dilakukan uji normalitas data untuk mengetahui distribusi data persentase lemak tubuh sebelum dan setelah senam Zumba. Berdasarkan uji normalitas data, diketahui bahwa data penelitian tidak terdistribusi normal $(P<0,05)$ sehingga digunakan uji nonparametrik yaitu uji Wilcoxon Signed Rank Test yang memperoleh nilai $P=0,065$. Hal ini menunjukkan bahwa tidak terdapat perbedaan persentase lemak tubuh sebelum dan setelah melakukan senam Zumba selama 4 minggu.

\section{BAHASAN}

Berdasarkan hasil penelitian, didapatkan nilai $P=0,065$ yang menunjukkan tidak terdapat perbedaan bermakna dari persentase lemak tubuh sebelum dan setelah melakukan senam Zumba. Walaupun demikian, data hasil pengukuran persentase lemak tubuh subjek setelah melakukan senam Zumba selama 4 minggu dengan frekuensi 3 kali dan durasi 60 menit memperlihatkan penurunan persentase lemak.

Ketika melakukan olahraga, tubuh memerlukan energi. Peningkatan kebutuhan energi berbanding lurus dengan penggunaan kalori cadangan tubuh. Ketika terjadi peningkatan penggunaan kalori, tubuh akan menggunakan cadangan energi yang salah satunya ialah lemak. ${ }^{7}$

Menurut American College of Sports Medicine, olahraga aerobik minimal 3-5 kali seminggu selama 20-60 menit dengan intensitas sebesar $60-90 \%$ dari frekuensi denyut jantung maksimal dapat meningkatkan metabolisme tubuh. Peningkatan metabolisme tubuh berkaitan dengan peningkatan kebutuhan kalori harian. Salah satu 
jenis olahraga aerobik ialah senam Zumba. ${ }^{8}$

Penelitian oleh Cakmakci et al. ${ }^{9}$ di Turki melaporkan terjadinya penurunan lemak tubuh rata-rata sebesar $3,5 \%$ setelah diberi intervensi senam aerobik selama 8 minggu dengan intensitas 3 kali per minggu dan durasi 60 menit. Dari penelitian tersebut, didapatkan bahwa senam aerobik yang dilakukan kurang dari 30 menit tidak berpengaruh secara bermakna terhadap penurunan lemak tubuh karena cadangan energi yang digunakan ketika berolahraga berasal dari glukosa. Senam aerobik yang dilakukan pada intensitas rendah sampai sedang dalam waktu 30 menit atau lebih efektif untuk membakar lemak. ${ }^{9}$

Penelitian lain yang dilakukan oleh Ossanloo et al. ${ }^{10}$ di Iran terhadap wanita yang diberikan intervensi tiga kombinasi olahraga yakni senam aerobik, step exercise, dan latihan resistensi selama 12 minggu dengan intensitas 3 kali per minggu dan durasi 60 menit menunjukkan terjadinya perubahan bermakna dari persentase lemak tubuh rata-rata sebesar 2,3\%. Juga didapatkan bahwa kombinasi tiga jenis olahraga meningkatkan kadar high density lipoprotein (HDL) wanita yang baik bagi kesehatan. $^{10}$

Thompson et al. ${ }^{11}$ meneliti pengaruh aktivitas fisik terhadap jaringan adiposa dan menyimpulkan bahwa terdapat perbedaan bermakna dari jaringan adiposa subjek yang rutin melakukan olahraga dan yang tidak rutin. Penelitian tersebut menunjukkan perubahan metabolisme lemak. Pada subjek yang tidak melakukan olahraga rutin, tidak ditemukan perubahan apapun pada ekspresi maupun serum adinopektin. Pada subjek yang melakukan olahraga rutin 5 kali seminggu selama 12 minggu, ditemukan peningkatan ekspresi adinopektin yang berperan dalam metabolisme lemak menjadi energi. Pada subjek yang melakukan olahraga rutin 5 kali seminggu selama 15 minggu selain terjadi peningkatan ekspresi adinopektin juga didapatkan penurunan mediator inflamasi yang berperan dalam obesitas.

Penelitian yang dilakukan Jaywant ${ }^{12}$ di Mumbai tentang pengaruh senam aerobik terhadap persebaran lemak tubuh dan ketahanan kardiovaskular (cardiovascular endurance) pada wanita usia pertengahan menyimpulkan bahwa senam aerobik selain dapat menurunkan persentase lemak tubuh secara bermakna $(P=0,01462)$, juga dapat meningkatkan cardiovascular endurance walaupun tidak signifikan.

Pada penelitian ini, tidak didapatkan perbedaan bermakna dari persentase lemak sebelum dan setelah melakukan senam Zumba. Berdasarkan data pengukuran didapatkan 12 subjek yang mengalami penurunan persentase lemak dan 4 subjek yang mengalami peningkatan persentase lemak. Perbedaan bermakna dari penurunan bahkan peningkatan persentase lemak disebabkan beberapa confounding factor seperti genetik, usia, asupan gizi, dan basal metabolic rate (BMR). Tiga dari empat subjek dengan peningkatan persentase lemak tubuh berusia di atas 40 tahun. Hal ini diduga karena saat memasuki usia 40 tahun, massa lemak tubuh akan bertambah bersamaan dengan penurunan massa bebas lemak. ${ }^{4}$

Limitasi penelitian ialah keterbatasan waktu penelitian. Penelitian ini dilakukan selama 4 minggu, sedangkan penelitianpenelitian yang menujukkan signifikansi perbedaan persentase lemak dilakukan selama 8-20 minggu, yang sesuai dengan teori bahwa diperlukan waktu minimal 8-10 minggu bagi fisiologi tubuh untuk merespon intervensi. ${ }^{13}$ Selain keterbatasan waktu, jumlah sampel terbatas.

Pengukuran persentase lemak pada penelitian ini dilakukan menggunakan Bioelectrical Impedance Analysis (BIA) jenis Family Dr Body Fat Monitor FEP 103. Alat ini kurang akurat dalam mengukur persentase lemak. Alat ukur yang paling spesifik dan akurat terhadap pengukuran persentase lemak tubuh ialah Dual-energy X-ray absorptiometry (DXA) yang menggunakan teknologi $X$-ray untuk memberi gambaran tentang komposisi tubuh. $^{14}$

\section{SIMPULAN}

Berdasarkan hasil penelitian ini dapat disimpulkan bahwa tidak terdapat perbe- 
daan persentase lemak tubuh yang bermakna sebelum dan setelah melakukan senam Zumba selama 4 minggu.

\section{SARAN}

Perlu dilakukan penelitian dengan cakupan lebih besar dan jangka waktu lebih lama dengan mengeksklusikan faktor-faktor perancu seperti usia.

Penelitian mengenai pengukuran persentase lemak tubuh sebaiknya menggunakan alat yang lebih spesifik yakni Dualenergy $X$ - ray absorptiometry (DXA) agar mendapatkan hasil yang lebih akurat.

Bagi wanita dewasa dihimbau untuk rajin melakukan aktivitas fisik dan berolahraga untuk menurunkan persentase lemak sehingga risiko untuk penyakit-penyakit metabolik dan kardiovaskular lebih rendah.

\section{DAFTAR PUSTAKA}

1. Fennema OR. Food chemistry (3rd ed). USA: Marcel Dekker, 1996; p. 9-22.

2. William M, Rawson E, Branch D. Nutrition for Health, Fitness \& Sport (11th ed). New York: McGraw-Hill Education, 2017; p. 44-6.

3. Nix S. William's Basic Nutrition and Diet Therapy (12th ed. Missouri: Elsvier Mosby, 2001.

4. Permana D. Pengaruh latihan aerobic class dan body language terhadap penurunan persentase lemak tubuh [Skiripsi]. Semarang: Universitas Negeri Semarang; 2014

5. Sukma AT. Efek Zumba terhadap penurunan tebal lemak bawah kulit dan berat badan member DF Fitness and Aerobic [Skripsi]. Yogyakarta: Universitas Negeri Yogyakarta; 2016.

6. Zumba Fitness: Sure it's fun but is it effective [Internet]. San Diego: American Council of Exercise; 2012 [cited 2018 Sep 20]. Available from: https://www. acefitness.org/certifiednewsarticle/2813 /zumba-fitness-sure-it-s-fun-but-is-iteffective

7. Irawan MA. Metabolisme energi tubuh \& olahraga. Sports Sciene Brief. Jakarta: Sports Science Brief, 2007.

8. Dalleck L, Dalleck A. The ACSM exercise intensity guidelines for cardiorespiratory fitness: Why the misuse. J Exerc Physiol Online. 2008;11(4):1-11.

9. Cakmakci E, Arslan F, Taskin H, Cakmakci O. The effects of aerobic dance exercise on body composition changes associated with change in sedentary women. Selcuk University Journal of Physical Education and Sport Science 2011;13(3):289-304.

10. Ossanloo P, Najar L, Zafari A. The effects combined training (aerobic dance, step exercise and resistance training) on body fat percents and lipid profile in sedentary females of Al Zahra University. European Journal of Experimental Biology 2012;2(5):1598-602.

11. Thompson D, Karpe F, Lafontan M, Frayn K. Physical activity and exercise in the regulation of human adipose tissue physiology. Physiol Rev. 2012;92:15791.

12. Jaywant PJ. Effect of aerobic dance on the body fat distribution and cardiovascular endurance in middle aged women. JESP. 2013;9(1):6.

13. Irianto DP. Pedoman Praktis Berolahraga Untuk Kebugaran Dan Kesehatan. Yogyakarta: Andi Publisher, 2004.

14. DXA/DEXA beats BMI: Using an X-ray exam to measure body composition \& fat loss [Internet]. San Fransisco: University Of California San Fransisco Department of Radiology and Biomedical Imaging; 2015 Oct 29 [cited 2018 Nov 19]. Available from: https://radiology.ucsf.edu/blog/dxadexa -beats-bmi-using-x-ray-exam-measurebody-composition-fat-loss 